\title{
Seasonal pattern in parasite infracommunities of Hoplerythrinus unitaeniatus and Hoplias malabaricus (Actinopterygii: Erythrinidae) from the Brazilian Amazon
}

\author{
Raissa Alves Gonçalves, Marcos Sidney Brito Oliveira, Ligia Rigôr Neves and Marcos Tavares-Dias* \\ Aquatic Organism Health Laboratory, Embrapa Amapá, 68903-419, Macapá, state of Amapá, Brazil
}

\begin{abstract}
The present study investigated the effects of seasonal variation in parasites infracommunities of Hoplerythrinus unitaeniatus and Hoplias malabaricus from a tributary of Amazon River. For H. unitaeniatus and H. malabaricus, 11 parasite species were similar, and greatest parasite richness occurred during the rainy season. Ichthyophthirius multifiliis was the dominant parasite species for both hosts. In H. unitaeniatus, infection by Whittingtonocotyle caetei, Whittingtonocotyle jeju, Urocleidoides sp. and Anacanthorus sp. was higher during rainy season. Contracaecum sp., Procamallanus (Spirocamallanus) inopinatus, Nomimoscolex matogrossensis and Gorytocephalus spectabilis showed no seasonal pattern. For H. unitaeniatus, P. pillulare, Clinostomum marginatum and Argulus pestifer occurred only during dry season, while Trichodina sp., Dolops geayi, undetermined metacercariae and Posthodiplostomum sp. occurred only during the rainy season. In H. malabaricus, the prevalence of Urocleidoides eremitus was similar during the two seasons, but abundance was higher during the rainy season. Tetrahymena sp., C. marginatum, Dendrorchis neivai, undetermined metacercariae, Posthodiplostomum sp., Genarchella genarchella, Cystidicoloides sp., G. spectabilis, D. geayi, A. pestifer and Glossiphonidae gen. sp. occurred only during the dry season. However, Contracaecum sp. and $P$. (S.) inopinatus occurred during both seasons, but the prevalence of $P$. (S.) inopinatus was higher during the rainy season. Seasonal variation in this infection levels was due to the host's feeding behavior and habits and the availability of infectious forms of parasites with heteroxenic life cycles. The non-seasonal fluctuation detected are likely a result of the parasites biology, highly variable nature of this tributary of Amazon River and low abundance of parasites.
\end{abstract}

\section{Keywords}

Amazon, Erythrinid, parasites, seasonal variation

\section{Introduction}

Hoplerythrinus unitaeniatus Spix and Agassiz, 1829 (Jeju or Aimara) and Hoplias malabaricus Bloch, 1794 (Thraira) are fish in the order Characiformes and family Erythrinidae, with wide distribution in South and Central America. These benthopelagic species are sedentary and occur in several types of fluvial and lacustrine environments, especially in shallow water environments and near submerged or marginal vegetation. They are piscivorous fish when adults, but juveniles also feed on plankton, crustaceans, insects and seeds. These species are habitually active at twilight and night and do not undertake migration (Santos et al. 2006; Soares et al. 2011; Alcântara and Tavares-Dias 2015). They are also commonly found in the Amazon River system, which is a complex ecosystem that in- cludes tributary rivers and streams, with floodplains and periodically flooded forest alongside them.

In South America, the parasites fauna of H. malabaricus has been constituted by species of Protozoa, Isopoda, Monogenoidea, Cestoda, Nematoda and Digenea. The parasites fauna of $H$. unitaeniatus has been comprised species of Protozoa, Argulidae, Monogenoidea, Cestoda, Nematoda, Acanthocephala and Digenea (Chambrier et al., 1996; Rocha 2011; Thatcher 2006; Alcântara and Tavares-Dias 2015). Parasite abundance and species richness have not been found to be affected by host body size, therefore indicating that factors other than host body size are more important determinants of variation of parasite abundance and species richness for the populations of both of these hosts Erythrinidae (Alcântara and Tavares-Dias 2015). One of the factors structuring these 
parasite communities in $H$. malabaricus and $H$. unitaeniatus may be the dry and rainy cycles from the eastern Amazon region. Therefore, can the parasites of $H$. unitaeniatus and $H$. malabaricus to suffer also seasonal influence?

In the eastern Amazon region, the tributaries of the Amazon River not only are strongly influenced by river tides, but also are influenced by the local rainfall regime (Takiyama et al. 2012; Tavares-Dias et al. 2014). Thus, seasonality in the Amazon basin is divided into a rainy season and a dry season. This dry/rainy season cycle may influence the life of the aquatic organisms and parasite infection levels in host fish (Kadlec et al. 2003; Thatcher 2006; Vital et al. 2011; Neves et al. 2013; Tavares-Dias et al. 2014). This knowledge provides information on different parasite species functions within a community, and also whether these parasitism levels are constant or whether variations are influenced by intermediate host availability. Such variations can alter the recruitment process of parasite species in the environment (Valtonen et 1990; Kadlec et al. 2003; Violante-González et al. 2008; Neves et al. 2013; Soylu 2013; Muñoz et al., 2013; Tavares-Dias et al. 2014). Therefore, the effects of seasonality on the parasite infracommunities in wild $H$. unitaeniatus and $H$. malabaricus populations in the Amazon region need to be addressed. Thus, this study investigated the effects of the rainy and dry seasons on parasite infracommunities in H. unitaeniatus and H. malabaricus from the eastern Amazon region, Northern Brazil.

\section{Material and Methods}

\section{Fish and collection locality}

Between February and December 2013, 69 specimens of H. unitaeniatus $(22.3 \pm 2.3 \mathrm{~cm}$ and $150.6 \pm 40.6 \mathrm{~g})$ and 67 specimens of $H$. malabaricus $(23.5 \pm 4.4 \mathrm{~cm}$ and $164.9 \pm 85.8 \mathrm{~g})$ were collected in the Igarapé Fortaleza basin $\left(00^{\circ} 00^{\prime} 56.3 \mathrm{~N}\right.$, $\left.051^{\circ} 05^{\prime} 27.1 \mathrm{~W}\right)$, a tributary of the Amazon River system, near the city of Macapá in the state of Amapá (Brazil), for parasitological analysis. All the fish were juveniles and adults not sexed, and were collected using fishing nets of different mesh sizes (20 $50 \mathrm{~mm}$ ) and transported packed in ice to the Aquatic Organism Health Laboratory from Embrapa Amapá, Macapá (AP).

In the eastern Amazon region of Brazil, there is a tropical climate region, and the rainy period occurs from December to May and the dry period from June to November (Souza and Cunha 2010). Seasonality was therefore based on the rainy season and dry season. Rainfall data were obtained from the Hydrometeorology and Renewable Energy Center (NHMET) of the Institute of Scientific and Technological Research of the State of Amapá (IEPA).

\section{Parasite collection procedures and data analysis}

The fish were necropsied and the mouth, opercula and gills were examined to detect ectoparasites. Gills were collected and fixed in formalin 5\%. Following this, all the entrails and the gastrointestinal tract were also examined to detect endoparasites using a stereoscopic microscope. They were collected, fixed in formalin 5\%, preserved in $70 \%$ ethyl alcohol, clarified or stained for identification (Eiras et al. 2006; Thatcher 2006). The identification of parasite taxa was based on specialized literature (Moravec 1998; Malta 1982; Chambrier et al. 1996; Thatcher 2006).

To analyze the parasite infracommunities, prevalence and abundance were taken into consideration, as recommended by Bush et al. (1997). The following descriptors for the parasite community were calculated: (1) species richness; (2) Brillouin diversity index $(H B)$; (3) evenness $(E)$ in association with diversity index; and (4) Berger-Parker dominance index $(d)$ and dominance frequency (percentage of the infracommunities in which a parasite species is numerically dominant (Rohde et al. 1995; Magurran 2004), using the Diversity software (Pisces Conservation Ltd., UK).

The Shapiro-Wilk test was used to determine whether the parasite abundance data followed a normal distribution pattern. Differences in parasite prevalence between rainy and dry periods and seasons were evaluated using the chi-square test $\left(\chi^{2}\right)$ and differences in parasite abundance were evaluated using the Mann-Whitney test $(U)$. For each host, the differences in species richness, diversity $(H B),(E)$ and dominance $(d)$, between rainy and dry periods and between host species, were determined using the Mann-Whitney test (U) (Zar 2010). Seasonal comparisons of parasite prevalence and abundance were done only for parasites with prevalence $>10 \%$.

Body weight $(\mathrm{g})$ and total length $(\mathrm{cm})$ data were used to calculate the relative condition factor $(\mathrm{Kn})$ of the hosts, compared with the standard value $(\mathrm{Kn}=1.0)(\mathrm{Le}-\mathrm{Cren} 1951)$. The values were described as the mean followed by standard deviation $( \pm \mathrm{SD})$ and range (minimum and maximum).

Differences in host $\mathrm{Kn}$ values, between the rainy and dry seasons, were compared using the Mann-Whitney test $(U)$. Correlations between host length and the species richness and Brillouin index were performed using Spearman's correlation coefficient (rs) (Zar 2010).

\section{Results}

During the rainy season, the mean water temperature was 29.6 $\pm 0.3^{\circ} \mathrm{C}$; $\mathrm{pH}$ was $6.1 \pm 0.4$; dissolved oxygen was $2.6 \pm 0.3$ $\mathrm{mg} \mathrm{L}^{-1}$ and rainfall was $362.2 \pm 136.1 \mathrm{~mm}$. During the dry season, the mean water temperature was $30.5 \pm 0.3^{\circ} \mathrm{C}$; $\mathrm{pH}$ was $6.3 \pm 0.3$; dissolved oxygen was $2.0 \pm 0.3 \mathrm{mg} \mathrm{L}^{-1}$ and rainfall was $87.9 \pm 62.8 \mathrm{~mm}$.

\section{Parasite infracommunities in Hoplerythrinus unitaeniatus}

All the fish examined were parasitized during both seasons, and a total of 1,262,019 parasites were collected during the dry season and 76,460 parasites during the rainy season. The parasite 


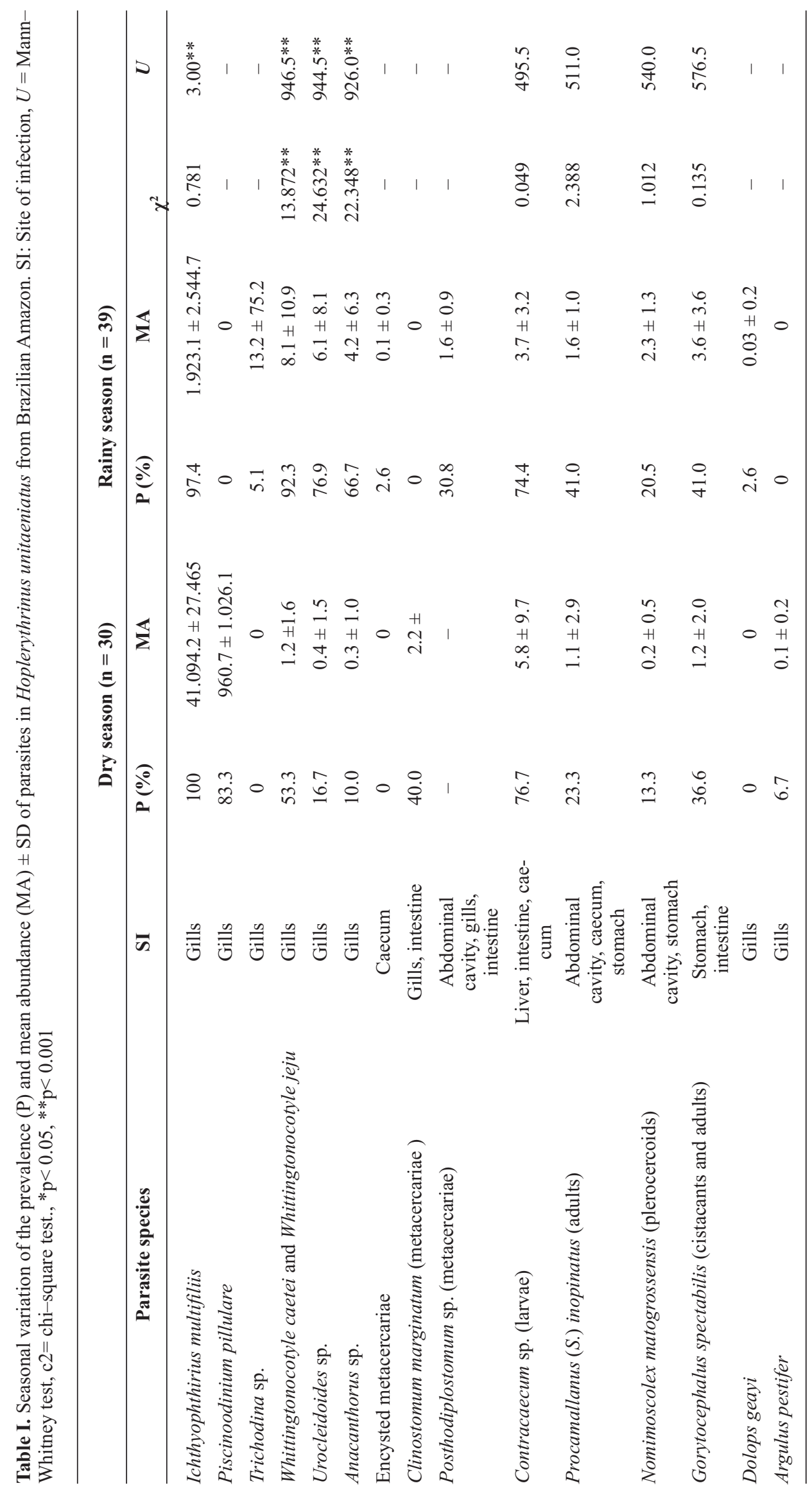


Table II. Differences in diversity indices between seasons for parasites collected from Hoplerythrinus unitaeniatus from Brazilian Amazon. $U$ : Mann-Whitney test

\begin{tabular}{lcccc}
\hline \multicolumn{1}{c}{ Diversity indices } & Dry season $(\mathbf{n}=\mathbf{3 0})$ & Rainy season $(\mathbf{n}=\mathbf{3 9})$ & $\boldsymbol{U}$ & $\boldsymbol{p}$ \\
\hline Species richness & $4.7 \pm 1.5(2-9)$ & $5.5 \pm 1.4(3-8)$ & 793.5 & 0.005 \\
Brillouin $(H B)$ & $0.13 \pm 0.08(0.003-0.304)$ & $0.16 \pm 0.21(0.006-1.080)$ & 520.0 & 0.435 \\
Evenness $(E)$ & $0.05 \pm 0.03(0.01-0.123)$ & $0.08 \pm 0.12(0.002-0.627)$ & 538.0 & 0.738 \\
Berger-Parker $(d)$ & $0.97 \pm 0.02(0.91-1.00)$ & $0.94 \pm 0.14(0.30-1.00)$ & 678.0 & 0.263 \\
\hline
\end{tabular}

community of $H$. unitaeniatus consisted of species of protozoa, monogeneans, digeneans, nematodes, cestodes, acanthocephalans and crustaceans. Ichthyophthirius multifiliis Fouquet, 1876 (Ichthyophthiriidae), was the most prevalent and abundant parasite in both seasons and showed higher abundance during the dry season. Infection due to Piscinoodinium pillulare Schäperclaus, 1954, Lom, 1981 (Oodiniaceae) and Argulus pestifer Ringuelet, 1948 (Argulidae) only occurred during the dry season. However, Trichodina sp.; Dolops geayi Bouvier, 1897 (Argulidae); undetermined digenean larvae and Posthodiplostomum sp. occurred only during the rainy season. Moreover, in the gills, the prevalence and abundance of monogenoideans Whittingtonocotyle caetei Santos-Neto, Rodrigues \& Domingues, 2015; Whittingtonocotyle jeju Santos-Neto, Rodrigues et Domingues, 2015; Urocleidoides sp. and Anacanthorus sp. (Dactylogyridae) were higher during the rainy season. Argulus pestifer occurred only during the dry season while $D$. geayi occurred only during the rainy season. The prevalence and abundance of Contracaecum sp., Procamallanus (Spirocamallanus) inopinatus Travassos, Artigas et Pereira, 1928 (Camallanidae), Nomimoscolex matogrossensis Rego et Pavanelli, 1990 (Monticellidae) and Gorytocephalus spectabilis Machado, 1959 (Neoechinorhynchidae) were similar during the rainy and dry seasons. However, $\mathrm{Cli}$ nostomum marginatum Rudolphi, 1819 (Clinostomidae) occurred only during the dry season while Posthodiplostomum sp. occurred only during the rainy season (Table I).

For H. unitaeniatus, I. multifiliis was dominant (dominance frequency, $\mathrm{DF}=0.970)$ during the dry season, followed by $P$. pillulare $(\mathrm{DF}=0.022)$; during the rainy season, $I$. multifiliis was also dominant $(\mathrm{DF}=0.980)$, followed by Trichodina $\mathrm{sp}$. $(\mathrm{DF}=0.006)$.

In H. unitaeniatus, species richness was higher during the rainy season, but the Brillouin index, evenness and BergerParker dominance did not differ between the dry and rainy seasons (Table II). During the dry season, hosts infected by 3 to 5 parasite species predominated, but during the rainy season, they presented 4 to 6 parasite species (Fig.1)

The H. unitaeniatus growth during the dry season $(\mathrm{b}=$ $\left.1.367 ; r^{2}=0.761\right)$ and rainy season $\left(b=1.532 ; r^{2}=0.899\right)$ was negative allometric, indicating greater increase in body weight than in size. Total $\mathrm{Kn}$ did not differ from the standard $\mathrm{Kn}=$ $1.00(U=2244.0 ; \mathrm{p}=0.753)$ and also did not differ between the dry and rainy seasons (Fig. 2), thus indicating good body conditions. The host weight during the dry season (148.1 \pm

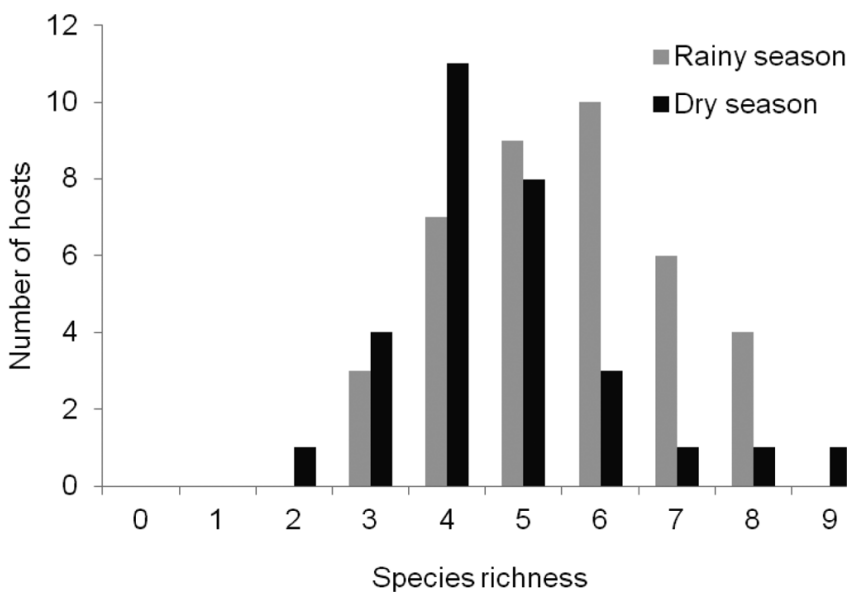

Fig. 1. Species richness of parasites during dry and rainy season for Hoplerythrinus unitaeniatus from Brazilian Amazon

$42.8 \mathrm{~g})$ was similar $(\mathrm{t}=-0.509 ; \mathrm{p}=0.614)$ to that of the rainy season $(152.4 \pm 43.5 \mathrm{~g})$. The host length during the dry season $(21.9 \pm 2.5 \mathrm{~cm})$ was also similar $(\mathrm{t}=-1.154 ; \mathrm{p}=0.258)$ to than host length during the rainy season $(22.6 \pm 2.0 \mathrm{~cm})$. Host length did not show any correlation with parasite species richness during the dry season $(r s=-0.041 ; \mathrm{p}=0.829)$ and rainy season ( $r s=0.064 ; \mathrm{p}=0.697$ ), and neither did the Brillouin diversity during the dry season $(r s=0.212 ; \mathrm{p}=0.261)$ and rainy season $(r s=-0.081 ; \mathrm{p}=0.624)$.

\section{Parasite infracommunities in Hoplias malabaricus}

All the fish were parasitized during both seasons and a total of 433,656 parasites were collected during the dry season and 206,935 parasites during the rainy season. The parasite community consisted of species of protozoa, monogeneans, digeneans, nematodes, cestodes, acanthocephalans, crustaceans and hirudineans. The ciliate I. multifiliis was the most prevalent and abundant parasite during both seasons and without any difference in infection levels between the seasons. The prevalence and abundance of $P$. pillulare were higher during the dry season. The prevalence of Urocleidoides eremitus Kritsky, Thatcher et Boeger, 1986 (Dactylogyridae) was similar during the two seasons, but its abundance was higher during the rainy season. Tetrahymena sp., $N$. matogrossensis, $C$. marginatum, Dendrorchis neivai Travassos, 1926, Posthodiplosto- 


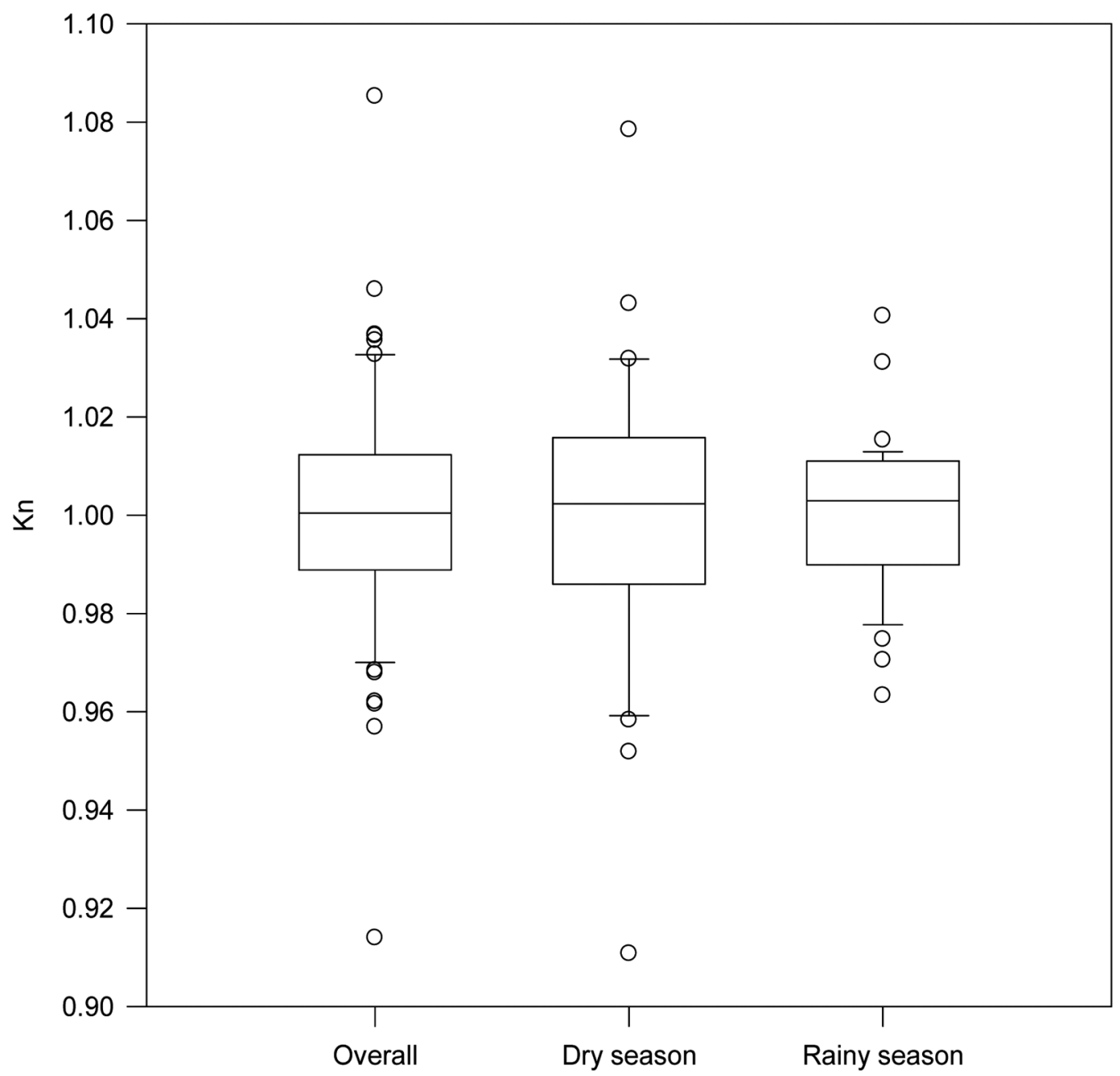

Fig. 2. Relative condition factor (Kn) of Hoplerythrinus unitaeniatus collected in the Brazilian Amazon. Box plots represent medians, interquartile ranges, minimum-maximum ranges and outliers. Equal mean values according to the Kruskal-Wallis test $(\mathrm{p}=0.879)$

mum sp., Genarchella genarchella Kohn et Fernandes, 1988, undetermined digenean larvae and G. spectabilis occurred only during the dry season. However, leeches Glossiphonidae, Cystidicoloides sp., D. geayi and A. pestifer occurred only during the rainy season, while Contracaecum sp. and $P$. $(S$.) inopinatus occurred during both seasons, but the prevalence of $P$. (S.) inopinatus was higher in rainy season (Table III).

For H. malabaricus, I. multifiliis was also dominant in the dry season (dominance frequency, $\mathrm{DF}=0.934$ ), followed by $P$. pillulare $(\mathrm{DF}=0.060)$ and $U$. eremitus $(\mathrm{DF}=0.002)$; during the rainy season, I. multifiliis was also dominant $(\mathrm{DF}=0.949)$, followed by $U$. eremitus $(\mathrm{DF}=0.030)$.

In $H$. malabaricus, there was no difference in the Brillouin index, evenness or Berger-Parker dominance index between the dry and rainy seasons. However, parasite species richness was higher during the rainy season (Table IV). During the dry season, there was predominance of hosts infected by 3 to 5 parasites, but during rainy season, the hosts presented 5 to 7 parasites (Fig. 3).

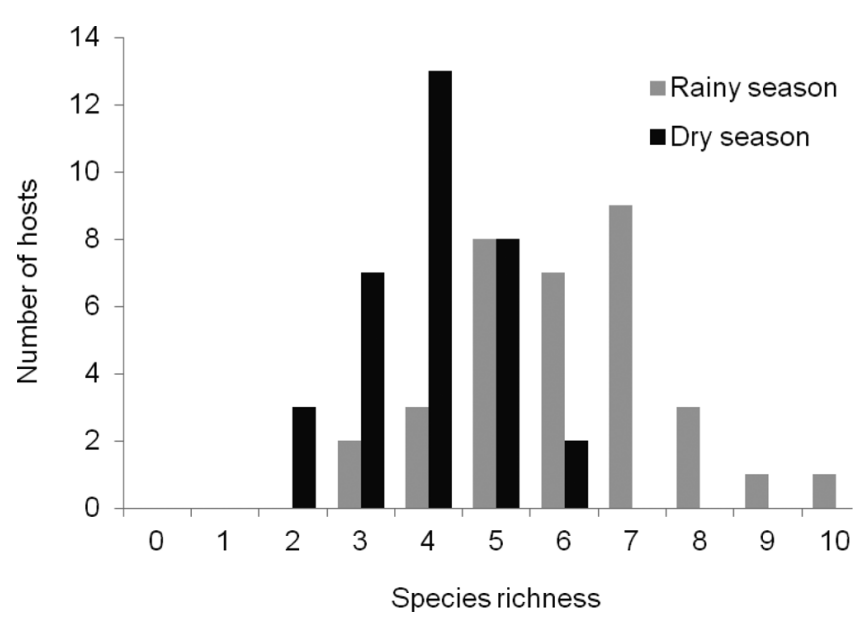

Fig. 3. Species richness of parasites during dry and rainy season for Hoplias malabaricus from Brazilian Amazon 


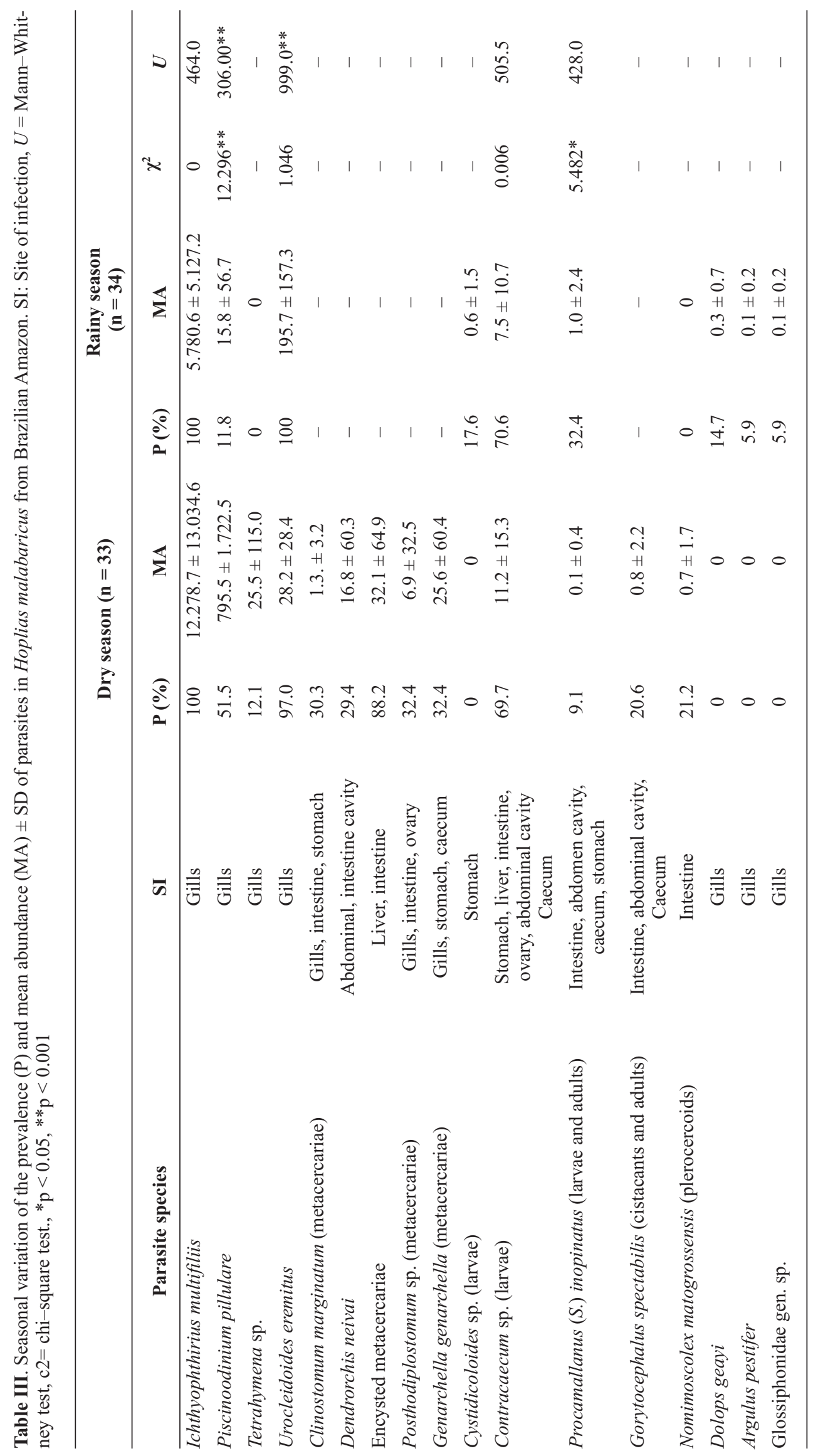


Table IV. Differences in diversity indices between seasons for parasites collected of Hoplias malabaricus from Brazilian Amazon. U: MannWhitney test

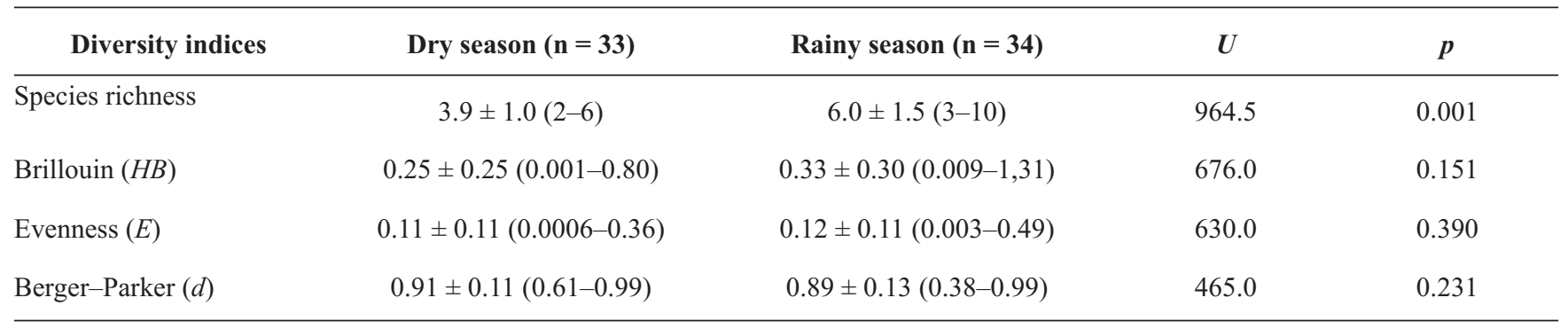

The $H$. malabaricus growth during the dry season $(\mathrm{b}=$ $\left.2.175 ; r^{2}=0.934\right)$ and rainy season $\left(b=1.978 ; r^{2}=0.944\right)$ was negative allometric, indicating that there was a greater increase in body weight than in size. Total $\mathrm{Kn}$ did not differ from the standard $\mathrm{Kn}=1.0(U=2077.0 ; \mathrm{p}=0.427)$ and also did not differ between the dry and rainy seasons (Fig. 4), thus indicating good body conditions, although host weight during the dry season $(113.8 \pm 43.7 \mathrm{~g})$ was significantly lower $(U=979.0 ; \mathrm{p}=$
$0.001)$ than during the rainy season $(214.4 \pm 87.9 \mathrm{~g})$. Host length during the dry season $(20.9 \pm 3.0 \mathrm{~cm})$ was also significantly lower $(t=-6.132 ; p=0.001)$ than host length during the rainy season $(26.0 \pm 0.6 \mathrm{~cm})$. Host length did not show any correlation with parasite species richness during the dry season $(r s=0.196 ; \mathrm{p}=0.275)$ and rainy season $(r s=-0.161 ; \mathrm{p}=$ $0.362)$, just as Brillouin diversity during dry season $(r s=0.168$; $\mathrm{p}=0.349)$ and rainy season $(r s=-0.083, \mathrm{p}=0.638)$.

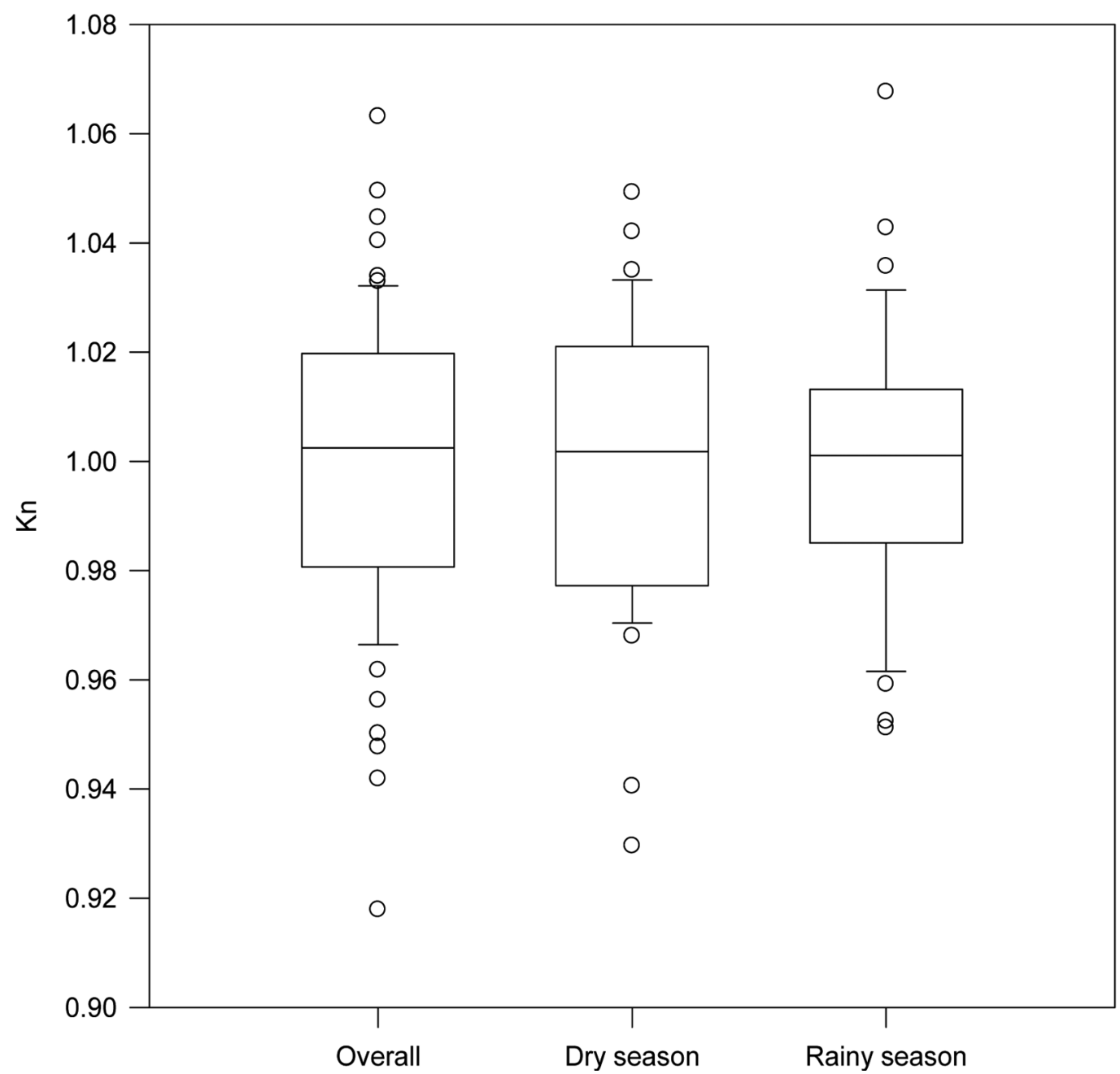

Fig. 4. Relative condition factor $(\mathrm{Kn})$ of Hoplias malabaricus collected in the Brazilian Amazon. Box plots represent medians, interquartile ranges, minimum-maximum ranges and outliers. Equal mean values according to the Kruskal-Wallis test $(p=0.977)$ 


\section{Discussion}

The $H$. unitaeniatus parasite community consisted of 3 species of protozoans and 12 of metazoans, of which seven were endoparasites and mostly in larval form. The H. malabaricus community consisted of 3 species of protozoans and 15 of metazoans, of which 11 were endoparasites species, mostly also in larval form. However, for both host species, 11 parasite species were common, and I. multifiliis was the dominant species. Ichthyophthirius multifiliis is an ectoparasite species with direct life cycle and great capacity for reproduction in eutrophic environments (Neves et al. 2013; Tavares-Dias et al. 2014; Majumder et al. 2015), such as the environment of the present study. The quantity of rainfall may have a great effect on aquatic ecosystems, resulting in changes to fish habitat and water velocity, which may influence fish life and therefore may affect the composition of the parasite communities and intermediate hosts. It may also lead to an increase in the physiological stress on the host fish and therefore make them more susceptible to parasite infections (Kadlec et al. 2003; TavaresDias et al. 2014). Both of the carnivorous fish, H. malabaricus and $H$. unitaeniatus, are benthopelagic and sedentary species that live in environments of stagnant or slowly running water and near submerged or marginal vegetation (Santos et al. 2006; Soares et al. 2011; Alcântara and Tavares-Dias 2015). They present higher endoparasite richness, with higher presence of the larval stage. Therefore, parasite assemblages could also play a potential role as environmental indicators by decreasing or increasing in their diversity, species richness, abundance and prevalence with the changes to environmental conditions (Kadlec et al. 2003; Tavares-Dias et al. 2014; Alcântara and Tavares-Dias 2015).

In wild fish populations, the endoparasite community structuring is related to host behavior, position in the food chain, seasonal availability of infecting forms in the environment and environmental conditions (Kadlec et al. 2003; Violante-González et al. 2008; Soylu 2013; Neves et al. 2013; Tavares-Dias et al. 2014; Majumder et al. 2015). Therefore, the similar lifestyles of $H$. malabaricus and $H$. unitaeniatus and their carnivorous habits, feeding on fish, crustaceans (Santos et al. 2006; Soares et al. 2011; Alcântara and Tavares-Dias 2015) and mollusks, contributed towards the elevated richness of endoparasites, which are transmitted trophically. In fish living in tropical fresh water, the highest endoparasite richness is generally observed in hosts with a diet based on macroinvertebrates and fish (Violante-González et al. 2008).

Seasonal variations may be reflected in parasite populations; hence, it can be expected that ectoparasites in particular, which have direct ties to the external environment, would not remain indifferent to the dry/rainy cycle changes (Neves et al. 2013; Tavares-Dias et al. 2014). In H. malabaricus and $H$. unitaeniatus, infections by I. multifiliis occurred in a similar manner during the rainy and dry seasons, but in $H$. unitaeniatus there was higher abundance during the dry season. Piscinoodinium pillulare occurred in the gills of
H. malabaricus during both seasons, but showed higher prevalence and abundance during the dry season. However, in H. unitaeniatus, infection by P. pillulare occurred only during the dry season, when there is a reduction of the environment in the basin studied here. However, low levels of infection by Trichodina sp. was found only in H. unitaeniatus and during the rainy season, while Tetrahymena sp. occurred only in $H$. malabaricus and during the dry season. The basin investigated here is strongly influenced by high loads of organic material from the Amazon River, and by local urban eutrophication (Tavares-Dias et al. 2014). The reduction of rainfall levels during the dry season increases this eutrophication, thereby favoring reproduction of these protozoans.

Due to seasonal changes that are reflected in parasite populations, monogenoidean species may present a negative or positive response to these changes, since these ectoparasites have a strong direct relationship with the external environment. Water temperature is the greatest factor influencing the seasonal occurrence of monogenoideans in temperate climatic regions. Variations in monogenoidean population size are strongly influenced by seasonal changes in environmental temperature, which directly affects the reproduction, survival time and behavior of these ectoparasites, as well as the behavior, density and responses of the hosts to infection levels. Thus, while some of them tend to reproduce more at a higher water temperature, others prefer a cool water temperature (Chubb, 1977; Valtonen et 1990; Soylu 2013). In contrast, in the Amazon region, the infection levels of these ectoparasites are strongly related to the hydrological cycle (Vital et al. 2011; Neves et al. 2013; Tavares-Dias et al. 2014).

In H. unitaeniatus and H. malabaricus there was infection by the monogenoideans $W$. caetei, $W$. jeju, U. eremitus, Urocleidoides sp. and Anacanthorus sp. during both seasons, but higher levels occurred during the rainy season. Therefore, these results indicate that reproduction among these dactylogyrids follow a well-defined pattern, i.e. with high prevalence and abundance throughout the year but with the highest peak of abundance during the rainy season. In contrast, higher infection levels by Gussevia asota Kritsky, Thatcher et Boeger, 1989, Gussevia astronoti Kritsky, Thatcher et Boeger, 1989 and Gussevia rogersi Kritsky, Thatcher et Boeger, 1989 in Astronotus ocellatus Agassiz, 1831 (Neves et al. 2013), and also by Gussevia alioides Kritsky, Thatcher et Boeger, 1986 and Gussevia disparoides Kritsky, Thatcher et Boeger, 1986 in Aequidens tetramerus Heckel, 1840 (Tavares-Dias et al. 2014), which occurred during the dry season in the eastern Amazon region. According Chubb (1977), seasonal differences between or within the different genera of monogenoideans are known to be related to their direct life cycle. Moreover, these results suggest that in the Amazon region, which has a similar temperature, the dactylogyrids species has developed a life strategy of its own in order to take advantage the dry/rainy season cycle. On the other hand, in temperate climatic regions, the temperature is the factor that directly affects the reproduction of dactylogyrids and the 
host response to parasitic infection (Chubb 1977; Valtonen et al. 1990; Kadlec et al. 2003).

In Brazil, the mollusks Biomphalaria spp. are the primary intermediate host of $C$. marginatum, several fish species are the secondary intermediate hosts and several fish-eating birds are the definitive hosts. Similarly, bivalve mollusks are the primary intermediate host of Posthodiplostomum nanum Dubois, 1937, fish species are the secondary intermediate hosts and fish-eating birds are the definitive hosts (Pinto and Melo 2012; Pinto et al. 2013; Pinto et al. 2015). Infections of C. marginatum occurred only in the dry season in $\mathrm{H}$. malabaricus and $H$. unitaeniatus while infections due to Posthodiplostomum sp. occurred during the rainy season in $H$. unitaeniatus and dry season in H. malabaricus. However, in $H$. malabaricus, the undetermined digenean larvae, D. neivai and G. genarchella, occurred only in the dry season. These results showed that a defined transmission pattern exists for the infectious forms of these digenean species for these two hosts, but with low overlapping of habitats. Seasonal variations in the abundance of intermediate hosts (mollusks) and definitive hosts (aquatic birds) can influence the availability of the digenean species (Chubb, 1979; Soylu 2013). During the dry season in the Amazon region, there is greater host density and greater overlap of the intermediate and definitive hosts in a shrunken environment, thereby facilitating the transmission of these digenean species (Tavares-Dias et al. 2014), which may be either ectoparasites or endoparasites of $H$. unitaeniatus and H. malabaricus.

Studies focusing on directly transmission of parasites have also reported a relationship between host abundance and the abundance of digeneans, both influenced by the dry/rainy season cycle (Violante-González et al. 2008; Muñoz et al., 2013). Moreover, environmental variations (Violante-González et al. 2008; Muñoz et al., 2013), vegetation cover and seasonal variations relating to the dietary behavior of $H$. malabaricus and $H$. unitaeniatus may also influence the seasonal infection patterns of metacercariae. These two host fish are piscivorous when adults, while the juvenile fish feeds on plankton, crustaceans, insects and seeds (Santos et al. 2006; Soares et al. 2011; Alcântara and Tavares-Dias 2015) and mollusks. This is the first record of D. neivai and G. genarchella for H. malabaricus.

In the basin of this study, there is greater food availability for the fish population during the rainy season (Gama and Halboth 2004). However, the foraging fish that form the intermediate hosts, along with crustaceans that contain some infectious forms of endoparasites, seemed to present greater food intake during the dry season. Other infectious forms of endoparasites presented availability in both seasons. For both H. malabaricus and H. unitaeniatus, infection due to Contracaecum sp. and $P$. (S.) inopinatus was not affected by seasonality. In contrast, for A. ocellatus (Neves et al. 2013) and Pygocentrus nattereri Kner, 1858 (Vital et al. 2011), there were higher levels of infection by these nematodes during the rainy season, due the seasonal dietary composition of these hosts, which includes microcrustaceans that are intermediate hosts of nematodes (Chubb, 1980; Moravec 1998; Soylu 2013). Cystidicoloides sp. occurred only in H. malabaricus and also during the rainy season. This is the first record of Cystidicoloides sp. for H. malabaricus. Moreover, in H. unitaeniatus, infection by G. spectabilis was not affected by the dry and rainy season, while low levels of infection by this acanthocephalan in H. malabaricus was found only during the dry season. Similarly, for A. tetramerus from the Amazon River system, low levels of infection by G. spectabilis also occurred only in the dry season (Tavares-Dias et al. 2014). These results indicate that a differentiated seasonal pattern exists regarding encounters by $H$. unitaeniatus and $H$. malabaricus with intermediate hosts containing larvae and adults forms of G. spectabilis. Therefore, these two erythrinid species are definitive hosts of $G$. spectabilis, which also use other fish species as intermediate or definitive hosts, to complete their life cycle in this region.

In the wild fish population, the seasonal cycle may influence the cestodes parasite populations. Thus, the dynamics of the process of recruitment of plerocercoids in copepods and maintenance of plerocercoid populations in the intermediate and definitive hosts could vary with the seasonal cycle. Some plerocercoids of cestodes are present in all seasons, and therefore they may be invasive to certain definitive and intermediate hosts in all seasons or only during some seasons of the year (Chubb, 1980; Soylu 2013). Diaptomus or cyclopoid copepods serve as intermediate hosts for development of metacestodes or plerocercoids of Proteocephalidea species, which are ingested later on by a secondary intermediate host fish (Scholz 1999; Soylu 2013). Our results indicate that $H$. unitaeniatus and $H$. malabaricus are intermediate hosts for $N$. matogrossensis, in the environment of this study, because both fish species had a constant and moderate level of $N$. matogrossensis infection throughout both seasons, except that $H$. malabaricus was infected only in the dry season. This difference in seasonality may result from the biology of these host fish or from differences in their immune response. Moreover, these erythrinid species had also low overlapping of habitats. Chambrier et al. 1996) also reported low levels of N. matogrossensis in H. malabaricus from Paraguay, and attributed this to seasonal effects regarding occurrences of this proteocephalid species. However, these authors considered that this fish could be either a typical host or an accidental host for this cestode.

Infection by $D$. geayi in $H$. malabaricus and $H$. unitaeniatus was low and occurred only during the rainy season. High infection levels by $D$. geayi in H. malabaricus in the central Amazon was also found during the rainy season (Malta 1982). Low occurrence of $A$. pestifer in $H$. unitaeniatus was found only during the dry season, but in H. malabaricus this was during the rainy season, when the hydrological levels facilitated encounters between these argulids with hosts. In Pseudoplatystoma spp. was reported higher infection levels of $A$.pestifer during the dry season, since this argulid seems to prefer turbid waters, given that it does not have body pigmentation to 
protect it from light that penetrates the water (Malta 1983). Another possible explanation for the seasonality of infection of these argulid species could be the effect of seasonal changes in local vegetation, and also the effects of tides of the Amazon River. Throughout the dry season, the aquatic vegetation facilitates proximity between $H$. malabaricus, $H$. unitaeniatus hosts and eggs of these argulids that are in vegetation. Moreover, lower rainfall levels mean that the tides of the Amazon River have less effect on the tributary river of this study, thereby facilitating encounters between these parasites and their hosts. However, these matters were not the focus of this investigation and therefore would need to be tested before any valid conclusions could be reached.

The condition factor can be used as a quantitative indicator for body conditions in fish populations in farmed and natural environmental situations (Guidelli et al. 2011). However, several factors may influence growth and the condition factor, including nutritional state, water temperature, stress, reproduction, parasitism and environmental alterations (Guidelli et al. 2011; Losee et al. 2014). H. malabaricus and H. unitaeniatus present both ectoparasites and endoparasites and the seasonality of these parasites does not affect the body conditions of these hosts, as also reported for A. tetramerus (Tavares-Dias et al. 2014). However, Oncorhynchus kisutch Walbaum, 1792 presents greater richness of endohelminths and showed better body conditions than fish with lower richness (Losee et al. 2014), thus indicating that fish with a higher condition factor can tolerate higher levels of parasitism. These differences in results may be related to different transmission strategies used by different parasites.

In summary, this first study on seasonality relating to H. malabaricus and H. unitaeniatus indicated that the Amazonian hydrological cycle, hosts' feeding behavior and seasonal availability of infectious forms in the environment were determining factors for seasonal variations of endoparasites infracommunities. Hoverer, the body size of the hosts was not an important factor in variations of species richness and diversity. Leeches and crustaceans were the least abundant species in the community structures of these two Amazonian hosts, which had high prevalence and abundance of generalist species such as I multifiliis and P. pillulare. The two erythrinid species are fish with similar life histories and that inhabit the same environment; however, the difference (about $39 \%$ ) in the parasites species found indicates that they had low overlapping of habitats, which was not expected. There were seasonal patterns for most of the parasite species; however, prolonged studies might indicate distinct annual patterns in parasite infracommunities relating to rainfall levels in different years. The non-seasonal fluctuation detected is likely to be a result of the parasites' biology, the highly variable nature of the Igarapé Fortaleza basin and the low abundance of parasites. Finally, for these natural fish populations, studies on the seasonal dynamics of parasite infracommunities and communities may provide supporting knowledge for use in fishing and fish farming.
Acknowledgements. The authors are grateful to the National Council for Research and Technological Development (Conselho Nacional de Pesquisa e Desenvolvimento Tecnológico, CNPq, Brazil) for its support through a research fellowship for M. Tavares-Dias.

\section{References}

Alcântara N.M., Tavares-Dias M. 2015. Study on the structure of the protozoan and metazoan communities of two Erythrinidae fish in the Amazonas River system (Brazil). Brazilian Journal of Parasitology Veterinary, 24, 183-190

Bush A.O., Lafferty K.D., Lotz J. M., Shostak, W. 1997. Parasitology meets ecology on its own terms: Margolis et al. Revisited. The Journal of Parasitology, 83, 575-583

Chambrier A., Scholz T., Vaucher C. 1996. Tapeworms (Cestoda: Proteocephalidea) of Hoplias malabaricus (Pisces: Characiformes, Erythrinidae) in Paraguay: description of Proteocephalus regoi sp. n., and redescription on Nomimoscolex matogrossensis. Folia Parasitologica, 43,133-140

Chubb J.C. 1977. Seasonal occurrence of helminths in freshwater fishes. Part I. Monogenea. Advances in Parasitology, 15,133-199

Chubb J.C. 1979. Seasonal occurrence of helminths in freshwater fishes. Part II. Trematoda. Advances in Parasitology, 17, $141-313$

Chubb J.C. 1980. Seasonal occurrence of helminths in freshwater fishes. Part III. Larval Cestoda and Nematoda. Advances in Parasitology, 18, 1-120

Eiras J.C., Takemoto R.M., Pavanelli G.C. 2006. Métodos de estudo e técnicas laboratoriais em parasitologia de peixes. 2. Ed. Eduem, Maringá, pp. 199

Gama C.S., Halboth D.A. 2004. Ictiofauna das ressacas das bacias do Igarapé da Fortaleza e do Rio Curiaú, In: Takiyama L.R., Silva, A.Q. Diagnóstico das ressacas do estado do Amapá: bacias do Igarapé da Fortaleza e Rio Curiaú CPAQ/IEPA e DGEO/SEMA, Macapá, AP, 23-52

Guidelli G., Tavechio W.L.G., Takemoto R.M., Pavanelli G.C. 2011. Relative condition factor and parasitism in anostomid fishes from the floodplain of the upper Paraná River, Brazil. Veterinary Parasitology, 177,145-151

Le-Cren, E.D. 1951. The length-weight relationship and seasonal cycle in gonadal weight and condition in the perch (Perca fluviatilis). Journal of Animal Ecology, 20. 201-219

Losee J.P., Fisher J., Teel D.J., Baldwin R.E., Marcogliese D.J., Jacobson K.C. 2014. Growth and condition of juvenile Coho salmon Oncorhynchus kisutch relate positively to species richness of trophically transmitted parasites. Journal of Fish Biology, 85, 1665-168

Magurran A.E. 2004. Measuring biological diversity. Blackwell Science, Oxford, $256 \mathrm{pp}$

Malta J.C.O. 1982. Os argulídeos (Crustacea: Branchiura) da Amazônia brasileira. 2.Aspectos da ecologia de Dolops geayi Bouvier, 1897 e Argulus juparanaensis Castro, 1950. Acta Amazonica, 12, 701-705

Malta J.C.O. 1983. Os argulídeos (Crustacea: Branchiura) da Amazônia brasileira.4. Aspectos da ecologia de Argulus multicolor Stekhoven, 1937 e Argulus pestifer Ringuelet, 1948. Acta Amazonica, 13, 489-496

Majumder S., Panda S.; Bandyopadhyay P.K. 2015. Effect of temperature on the prevalence of different parasites in Cirrhinus mrigala Hamilton of West Bengal. Journal of Parasitic Diseases, 39,110-112

Moravec F. 1998. Nematodes of freshwater fish of the Neotropical region. Academia of Sciences of the Czech Republic, Praha, pp. 464 
Muñoz G., Torres P., Valdés J., Rodríguez A. 2013. Spatio-temporal variation in the prevalence of trematodes in the bivalve $\mathrm{Pe}$ rumytilus purpuratus. Acta Parasitologica, 58, 155-166

Neves L.R., Pereira F.B., Tavares-Dias M.T., Luque J.L. 2013. Seasonal influence on the parasite fauna of a wild population of Astronotus ocellatus (Perciformes: Cichlidae) from the Brazilian Amazon. Journal of Parasitology, 99, 718-721

Pinto H.A., Melo A.L. 2012. Infecção natural de Poecilia reticulata (Actinopterygii: Poeciliidae) por metacercárias na Represa da Pampulha, Belo Horizonte, Minas Gerais, Brasil. Boletim do Instituto de Pesca, 38, 257-264

Pinto H.A., Mati V.L.T., Melo, A.L. 2013. New records and a checklist of trematodes from Butorides striata (Aves: Ardeidae). Revista Mexicana de Biodiversidad, 84, 1100-1110

Pinto H.A., Caffara M.; Fioravanti M.L., Melo A.L. 2015. Experimental and molecular study of cercariae of Clinostomum sp. (Trematoda: Clinostomidae) from Biomphalaria spp. (Mollusca: Planorbidae) in Brazil. Journal of Parasitology, 101, 108-113

Kadlec D., Simkova A., Jarkovsky J. 2003. Parasite communities of freshwater fish under flood conditions. Parasitology Research, 89, 272-283

Rocha CAM. 2011. Parasitic helminths of the freshwater Neotropical fish Hoplias malabaricus (Characiformes, Erythrinidae) from South America basins. Reviews in Fisheries Science, 19, 150-156

Rohde K., Hayward C., Heap M. 1995. Aspects of the ecology of metazoan ectoparasites of marine fishes. Journal of Parasitology, 25, 945-970

Santos G. M., Ferreira E.J.G., Zuanon J.A.S. 2006.Peixes comerciais de Manaus. ProVárzea, Manaus: Ibama/AM, pp. 146

Sholz T. 1999. Lifes cycles of species of Proteocephalus, parasites of fishes in the Palearctich region: a review. Journal of Helminthogy, 73, 1-19

Soares M.G.M., Costa E. L., Siqueira-Souza, F. K., Anjos H.D.B., Yamamoto K.C., Freitas C.E.C. 2011. Peixes de lagos do médio Rio Solimões. $2^{\mathrm{a}}$ ed. Reggo Editora, Manaus, pp. 175

Received: April 6, 2015

Revised: August 13, 2015

Accepted for publication: September 25, 2015
Souza E.B., Cunha A.C. 2010. Climatologia de precipitação no estado do Amapá e mecanismos climáticos de grande escala. In: Cunha A. C., Souza E.B., Cunha, H. F.A. Tempo, clima e recursos hídricos: resultados do Projeto REMETAP no estado do Amapá. Macapá, 177-195

Soylu E. 2013. Metazoan parasites of perch Perca fluviatilis L. from Lake Sığırcı, Ipsala, Turkey. Pakistan Journal of Zoology, $45,47-52$

Thatcher VE. 2006. Amazon fish parasites. $2^{\text {th }}$ ed. Pensoft Publishers, Sofia, $509 \mathrm{pp}$

Takiyama L.R., Silva U.R.L., Jimenez E.A., Pereira R.A., Zacardi, D.M., Fernandes E. F., Souto F.A. F., Silva L.M.A., Silva M.S., Santos M.A. Costa-Neto S.V., Santos, V. F. 2012. Zoneamento ecológico econômico urbano das áreas de ressacas de Macapá e Santana, Estado do Amapá. IEPA, Macapá, AP, pp. 84

Tavares-Dias M., Oliveira M.S.B., Gonçalves R.A., Silva L.M. A. 2014. Ecology and seasonal variation of parasites in wild Aequidens tetramerus, a Cichlidae from the Amazon. Acta Parasitologica, 59, 158-164

Violante-González J., Rojas-Herrera A., Aguirre-Macedo M.L. 2008. Seasonal patterns in metazoan parasite community of the "Fat Sleeper" Dormitator latifrons (Pisces: Eleotridae) from Tres Palos Lagoon, Guerrero, Mexico. Revista de Biologia Tropical, 56, 1419-1427

Vital J.F., Varella A.M.B., Porto D.B., Malta, J.C.O. 2011. Sazonalidade da fauna de metazoários de Pygocentrus nattereri (Kner, 1858) no lago Piranha (Amazonas, Brasil) e a avaliação de seu potencial como indicadora da saúde do ambiente. Biota Neotropica, 11, 199-204

Valtonen E. T., Prost M., Rahkonen R. 1990. Seasonality of two gill monogeneans from two freshwater fish from an oligotrophic lake in Northeast Finland. International Journal for Parasitology, 20,101-107

Zar J.H. 2010. Biostatistical analysis. $5^{\text {th }}$ Ed. Prentice Hall, New Jersey, pp. 944 